\title{
Accumulation of polycyclic aromatic hydrocarbons (PAHs) on the spider webs in the vicinity of road traffic emissions
}

\author{
Justyna Rybak • Teresa Olejniczak
}

Received: 13 June 2013 / Accepted: 23 August 2013 / Published online: 22 September 2013

(C) The Author(s) 2013. This article is published with open access at Springerlink.com

\begin{abstract}
Studies focused on the possible use of spider webs as environmental pollution indicators. This was a first time ever attempt to use webs as indicators of polycyclic aromatic hydrocarbons (PAHs) pollution. The aim of the study was (a) to evaluate whether webs are able to accumulate PMassociated road traffic emissions and be analyzed for organic toxics such as PAHs, (b) to assess if the distance from emission sources could have an influence on the accumulation level of pollutants, and (c) to determine types of pollution sources responsible for a structure of monitoring data set. Webs of four species from the family Agelenidae were sampled for PAHs presence. Data from vehicle traffic sites (i.e., road tunnel, arterial surface road, underground parking) and from railway traffic sites (i.e., two railway viaducts) in the city of Wroclaw (Southwest of Poland) showed a significantly higher mean concentrations of PAHs than the reference site 1 (municipal water supply works). We also found a significant differences at sites differed by the distance from emission sources. The result of PCA analysis suggested three important sources of pollution. We conclude that spider webs despite of some limitations proved useful indicators of road traffic emissions; they could be even more reliable compared to use of
\end{abstract}

Responsible editor: Ester Heath

Electronic supplementary material The online version of this article (doi:10.1007/s11356-013-2092-0) contains supplementary material, which is available to authorized users.

\footnotetext{
J. Rybak $(\bowtie)$

Department of Environmental Protection, Wroclaw University of Technology, Wybrzeże Wyspiańskiego 27, 50-370 Wrocław, Poland e-mail: justyna.rybak@pwr.wroc.pl

T. Olejniczak

Chemistry Department, Wrocław University of Environmental and

Life Science, C.K. Norwida 25/27, 50-375 Wrocław, Poland

e-mail: teresa.olejniczak@up.wroc.pl
}

bioindicators whose activity is often limited by a lack of water and sun.

Keywords Spider webs $\cdot$ Polycyclic aromatic hydrocarbons (PAHs) · Road traffic emission · Environmental indicators . Principal component analysis (PCA)

\section{Introduction}

Dust suspended in the air, especially particles of soot, constitutes an important threat to human health. Due to its size (dust of particulate matter 2.5 and 1), it can easily enter the lungs. Dust is characterized by a high adsorption capacity, and therefore, on its surface, a great variety of toxic substances are easily deposited, including carcinogenic polycyclic aromatic hydrocarbons (PAHs) and heavy metals and their compounds (Jermann et al. 1989). A significant part of dust is produced by motor vehicles. A source of toxic emissions of PAHs is diesel engines (Zhu et al. 2002). Polycyclic aromatic hydrocarbons, a group of compounds with the most known and toxic benzo $[a]$ pyrene, are formed during the incomplete combustion of organic matter, including fossil fuels (Sapkota and Buckley 2003). Many of them exhibit carcinogenic and mutagenic properties. The US Environmental Protection Agency has recognized 16 PAHs as priority pollutants, and the European Union has established a health-based standard for PAHs in air as $1 \mathrm{ng} \mathrm{m}^{-3}$ (expressed as a concentration of benzo $[a]$ pyrene over 1 year as average period, EU Directive 2004/107/EC and Regulation 219/2009) (De Nicola et al. 2011). Therefore, in the recent years, research focusing on the risks resulting from the emission of pollutants has been increased; several experiments were done in tunnels because of their specific characteristics discussed later in this article (Laschober et al. 2004; Zechmeister et al. 2006). PAH concentrations in air are affected by climate and chemical- 
physical properties of particular compounds. PAHs are present in the atmosphere in vapor and particle-bound phase and can be deposited on soil, water, sediments, and living organism tissues by wet and dry deposition (De Nicola et al. 2011). Vegetation is an effective media for catchment of these compounds mainly through atmospheric deposition (Ratola et al. 2012). Several taxa have been commonly used as biomonitors, such as mosses, lichens, and tree leaves (Shukla and Upreti 2009; Prajapati and Triphati 2008; Zechmeister et al. 2006). Pine needles are considered as an important matrix for the biomonitoring of PAHs because of their relatively long life-span and lipidic waxy cover prone to accumulate airborne contaminants (Ratola et al. 2010; 2012).

In literature, issues reported the use of spider webs for the indication of pollution were studied few times only (Hose et al. 2002; Xiao-li et al. 2006; Rybak et al. 2012). The findings are very interesting and require continuation (Hose et al. 2002; Xiao-li et al. 2006). Apart from the authors of this paper, webs of four species have been studied until now (the presence of heavy metals and water-soluble ions were analyzed), among them only one occur in Poland. The usefulness of spider webs to heavy metals pollution indication has been proved in the abovementioned research. Spider silk is a protein compound (fibroine) (Foelix 1996), which may show, as we suppose, on the basis of molecular interaction (as every protein), chemical affinity for aromatic compounds which are present in the air (immobilization on spider webs).

As a rule, active and passive biomonitoring with mosses and lichens or plant leafs is used for estimating ambient air pollution caused by traffic (Orlinski 2002; Zechmeister et al. 2006). Usually, compound concentrations measured by bioindicators have a wide range of sources. They may be at close or long range, which sometimes results in difficulties with identification of emission sources causing an accumulation of toxic compounds in plant tissues (Zechmeister et al. 2006). This problem is minimalized greatly in tunnels. All compounds accumulating in the body of living organisms or in their products are associated with in situ emissions (Zechmeister et al. 2006). Moreover, compounds are not rinsed with the rain. In these specific conditions (lack of sunlight and water, etc.), the use of spider webs for road traffic emissions indication seems preferable to applying plants or even standard procedures of air pollution assessment. In the case of plants, a lack of water and sun can significantly affect the level of accumulation of compounds in the tissues; the use of the impactor requires a constant supervision which is impossible in tunnels or viaducts.

In this paper, the webs of four species of spiders from the family Agelenidae inhabiting tunnels, viaducts, car parks, and open space were analyzed.

The purpose of our research was to answer to the following questions:

First, whether spider webs are able to accumulate PMassociated road traffic emissions (PAHs); second, to determine if the efficacy of application of spider webs as environmental indicators of PM-associated organic air pollutants depends on proximity to emission sources; third, can spider web-sampled PAH data be used to indicate road traffic emissions when analyzed by receptor modeling techniques such as principal component analysis (PCA)?

\section{Material and methods}

\section{Overview}

The advantages of webs usage for this purpose are as follows: the low-cost of samples collection, availability of research material, the secluded location of webs (in the passageways such as bridges, viaducts, and tunnels) preventing their destruction by atmospheric conditions (rain, wind, etc.) and decomposition of PAHs by sunrays and microorganisms (which is often the case when using other biomonitors), noninvasiveness (there is no need to kill animals), ease of samples collection, and a wider choice of monitoring sites comparing to the use of plants which are dependent on sunlight (Rybak et al. 2012; Xiao-li et al. 2006). It was also found that an additional advantage is the webs' ability to accumulate toxins over a long period of time (60 days), thereby allowing the monitoring of pollution level over a defined period of time almost at any selected location in contrast to plants where, regarding to climatic limitations, some monitoring sites are not available for them. The application of the impactors in standard monitoring system is also impossible in any location because the constant supervision is needed as the expensive and inconvenient equipment (large and loud) is usually used. What is more, such application provides only information about the temporary state of the environment (Xiao-li et al. 2006). Thus, spider webs share many characters of an ideal indicator.

\section{Sampling sites}

The research was conducted in the year 2011 (spring, summer, and autumn), nine sites within Wrocław, Poland, were selected on the basis of spatial analysis of research area taking into account the abiotic conditions (spring: min-max temperature $6.1-16.5^{\circ} \mathrm{C}$, rainfall $48 \mathrm{~mm}$, relative humidity $66 \%$; summer: min-max temperature $12.4-23.6{ }^{\circ} \mathrm{C}$, rainfall $69 \mathrm{~mm}$, relative humidity $70 \%$; autumn: min-max temperature $4.6-19.3{ }^{\circ} \mathrm{C}$, rainfall $46 \mathrm{~mm}$, relative humidity $75 \%$ ). Description of sites and sample collection procedure was presented in Table 1 (altogether with number of collected samples at each site). The location of the sampling sites is shown in Fig. 1. Sites were located near vehicle traffic (i.e., road tunnel, arterial surface road, and underground parking), near railway traffic (i.e., two railway viaducts), and reference sites (i.e., urban 
Table 1 Description of sampling sites

\begin{tabular}{|c|c|c|c|}
\hline Site & Description & Location & Sample collection \\
\hline $\begin{array}{l}\text { 1-Reference site: } \\
\text { municipal water } \\
\text { supply works }\end{array}$ & $\begin{array}{l}\text { Hydraulic construction in the drinking water supply area of } \\
\text { Wrocław, which is situated in the Southeastern part of the } \\
\text { city. The flat grassy area is about } 1,026 \text { ha overgrown } \\
\text { with bushes and trees. This place is }>8 \mathrm{~km} \text { away from the } \\
\text { main routes. The use of vehicles is prohibited here. }\end{array}$ & $\begin{array}{l}\mathrm{N} 51^{\circ} 6^{\prime} 9.0896^{\prime \prime} / \\
\mathrm{E} 17^{\circ} 3^{\prime} 55.0319^{\prime \prime}\end{array}$ & $\begin{array}{l}\text { Spider webs of } M \text {. silvestris were collected } \\
\text { from a height of about } 1 \mathrm{~m} \text { from the } \\
\text { building walls of short tunnel (a few meters) } \\
(n=6) \text {. }\end{array}$ \\
\hline $\begin{array}{l}\text { 2-Reference site: } \\
\text { urban residential }\end{array}$ & $\begin{array}{l}\text { Biskupin, settlement in the Eastern part of the city in the } \\
\text { district of Sródmieście. The environment is diverse } \\
\text { including allotments, park, and high and low buildings } \\
\text { (tenement houses and villas). }\end{array}$ & $\begin{array}{l}\mathrm{N} 51^{\circ} 6^{\prime} 3.4628^{\prime \prime} / \\
\mathrm{E} 17^{\circ} 5^{\prime} 40.8611^{\prime \prime}\end{array}$ & $\begin{array}{l}\text { Webs of spiders } M \text {. ferruginea were collected } \\
\text { from the walls (aprox.1.50 m) }(n=7) \text {. }\end{array}$ \\
\hline $\begin{array}{l}\text { 3-Underground } \\
\text { parking I }\end{array}$ & $\begin{array}{l}\text { Underground parking at Grunwaldzki square localized in the } \\
\text { Northeast of Wrockaw, the main communication junction } \\
\text { with a high-intensity car traffic } 24 \text { h a day ( } 8,365 \text { vehicles } \\
\text { per hour). Due to the lack of downtown ring road, cars } \\
\text { and trucks are forced to overcome this road coming. }\end{array}$ & $\begin{array}{l}\mathrm{N} 51^{\circ} 6^{\prime} 39.4637^{\prime \prime} / \\
\mathrm{E} 17^{\circ} 3^{\prime} 29.0381^{\prime \prime}\end{array}$ & $\begin{array}{l}\text { M. ferruginea webs were collected from walls } \\
\text { of parking (aprox. } 2 \mathrm{~m} \text { in the center). Site } \\
\text { was just about } 15 \mathrm{~m} \text { away from the busy } \\
\text { street }(n=7) \text {. }\end{array}$ \\
\hline $\begin{array}{l}\text { 4-Underground } \\
\text { parking II }\end{array}$ & $\begin{array}{l}\text { The site near the former one (site } 3 \text { ) about } 70 \mathrm{~m} \text { from the } \\
\text { axis of Grunwaldzka designed for a comparative analysis } \\
\text { of PAHs content depending on the distance from emission } \\
\text { sources. }\end{array}$ & $\begin{array}{l}\mathrm{N} 51^{\circ} 6^{\prime} 40.7367^{\prime \prime} / \\
\mathrm{E} 17^{\circ} 3^{\prime} 29.0381^{\prime \prime}\end{array}$ & $\begin{array}{l}\text { Webs of } M \text {. ferruginea were also collected } \\
\text { from walls at the outlet of car park (height } \\
\text { of } 1-2 \mathrm{~m})(n=5) \text {. }\end{array}$ \\
\hline $\begin{array}{l}\text { 5-Railway } \\
\text { viaduct }\end{array}$ & $\begin{array}{l}\text { The railway viaduct near Starograniczna street with a length } \\
\text { of } 10 \mathrm{~m} \text { located in a low traffic area }(70 \text { vehicles per } \\
\text { hour), but in the vicinity of the busy street }(20 \mathrm{~m}) \text {. }\end{array}$ & $\begin{array}{r}\mathrm{N} 51^{\circ} 7^{\prime} 32.6444^{\prime \prime} / \\
\mathrm{E} 17^{\circ} 0^{\prime} 1.8986^{\prime \prime}\end{array}$ & $\begin{array}{l}\text { Webs of } T \text {. atrica were collected from the } \\
\text { walls at a height of } 1 \mathrm{~m} \text { in the viaduct } \\
\text { center }(n=5) \text {. }\end{array}$ \\
\hline $\begin{array}{l}6 \text { - Second railway } \\
\text { viaduct }\end{array}$ & $\begin{array}{l}\text { The railway viaduct with a length of } 7 \mathrm{~m} \text {. The viaduct is also } \\
\text { located in a quiet place with a low traffic ( } 84 \text { vehicles per } \\
\text { hour) but in a short distance }(50 \mathrm{~m}) \text { from the busy main } \\
\text { route (Długa street). }\end{array}$ & $\begin{array}{l}\mathrm{N} 51^{\circ} 7^{\prime} 18.269^{\prime \prime} / \\
\mathrm{E} 17^{\circ} 0^{\prime} 12.945^{\prime \prime}\end{array}$ & $\begin{array}{l}\text { Webs of } T \text {. atrica were collected from the } \\
\text { central walls of the viaduct at a height of } \\
2 \mathrm{~m}(n=18) .\end{array}$ \\
\hline $\begin{array}{l}\text { 7-Arterial surface } \\
\text { road I }\end{array}$ & $\begin{array}{l}\text { Hedges along crossroad. According to the report of the } \\
\text { Regional Inspectorate for Environmental Protection, } \\
\text { Wrocław branch (Wojewódzki Inspektorat Ochrony } \\
\text { Srodowiska 2012) one of the most important places for } \\
\text { communication system of the city (10,324 vehicles per } \\
\text { hour), it highly contributes to the deterioration of the } \\
\text { environment. }\end{array}$ & $\begin{array}{l}\mathrm{N} 51^{\circ} 5^{\prime} 11.0663^{\prime \prime} / \\
\text { E17º } 0^{\prime} 44.6938^{\prime \prime}\end{array}$ & $\begin{array}{l}\text { Webs of } M \text {. ferruginea were collected directly } \\
\text { from the hedges of Ligustrum vulgare } \\
\text { (height of } 2.5 \mathrm{~m} \text { ) beside the road. Site } 7 \text { was } \\
\text { just about } 10 \mathrm{~m} \text { from the busy street }(n=10) \text {. } \\
\text { Other species }(M . \text { silvestris, T. agrestis, and } \\
\text { T. atrica) were also present at this site and } \\
\text { were used for comparisons of interspecific } \\
\text { variability }(n=19) \text {. }\end{array}$ \\
\hline $\begin{array}{l}\text { 8-Arterial surface } \\
\text { road II }\end{array}$ & $\begin{array}{l}\text { Site near the previous one (site } 7 \text { ) about } 60 \mathrm{~m} \text { in a straight } \\
\text { line from the road designated to compare PAHs content } \\
\text { depending on the distance from emission sources. }\end{array}$ & $\begin{array}{l}\mathrm{N} 51^{\circ} 5^{\prime} 10.5568^{\prime \prime} / \\
\mathrm{E}^{\prime} 7^{\circ} 0^{\prime} 46.5863^{\prime \prime}\end{array}$ & $\begin{array}{l}\text { Webs of } M \text {. ferruginea were collected directly } \\
\text { from the hedges of Ligustrum vulgare } \\
\text { (height of } 2.5 \mathrm{~m})(n=7) \text {. }\end{array}$ \\
\hline 9-Road tunnel & $\begin{array}{l}\text { Road tunnel with a length of } 90 \mathrm{~m} \text { at Pulaskiego street. The } \\
\text { city center and at the same time the bottleneck due to a } \\
\text { heavy traffic and frequent congestions ( } 9,812 \text { vehicles per } \\
\text { hour) (WIOS 2012). }\end{array}$ & $\begin{array}{l}\mathrm{N} 51^{\circ} 5^{\prime} 48.8614^{\prime \prime} / \\
\mathrm{E} 17^{\circ} 2^{\prime} 32.1452^{\prime \prime}\end{array}$ & $\begin{array}{l}\text { Webs of } T \text {. agrestis were collected from the } \\
\text { walls of the tunnel (height of } 2 \mathrm{~m} \text {, centrally } \\
\text { located webs were selected only) }(n=8) \text {. }\end{array}$ \\
\hline
\end{tabular}

residential and municipal water supply works). At two sites of particularly high traffic (8,365 vehicles per hour and 10,324 vehicles per hour, transit routes), webs were collected at different distances (10-20 and 60-70 m) from the source of emission (road) (sites 3 and 4; sites 7 and 8).

Spider species selected as indicators

Four species from the family Agelenidae, Malthonica silvestris (1. Koch, 1872), Malthonica ferruginea (Panzer, 1804), Tegenaria agrestis (Walckenaer, 1802), and Tegenaria atrica (C.L. Koch, 1843) were used. As many as four species were selected because they were not present at the same time at all selected sites. A selection of species for research was based also on eating behavior (some species used to eat their old web which could affect the results of studies, e.g., Araneidae family, which are not the subject of our research). A web construction behavior of Agelenids was also observed (webs of this family occur the most frequent; thus, they have been chosen for our studies), and we have not observed the habit of eating an old web. Agelenidae webs are not sticky and consist of an open tube, which extends from the front into a funnel and its lower part in a vast carpet of silk with numerous threads signalizing the victims passing (Roberts 1995). Agelenids prefer dark, abandoned, and neglected buildings; they commonly occur in tunnels and under bridges where they weave comprehensive, easily recognizable webs. In addition, some species are characterized by all yearround activity even at low temperatures (Roberts 1995). These 
Fig. 1 Location of research sites in Wrocław. Reference sites: 1 municipal water supply works, 2 urban residential, traffic sites, 3 underground parking I, 4 Underground parking II, 5 railway viaduct I, 6 railway viaduct II, 7 arterial surface road I, 8 arterial surface road II, 9 road tunnel

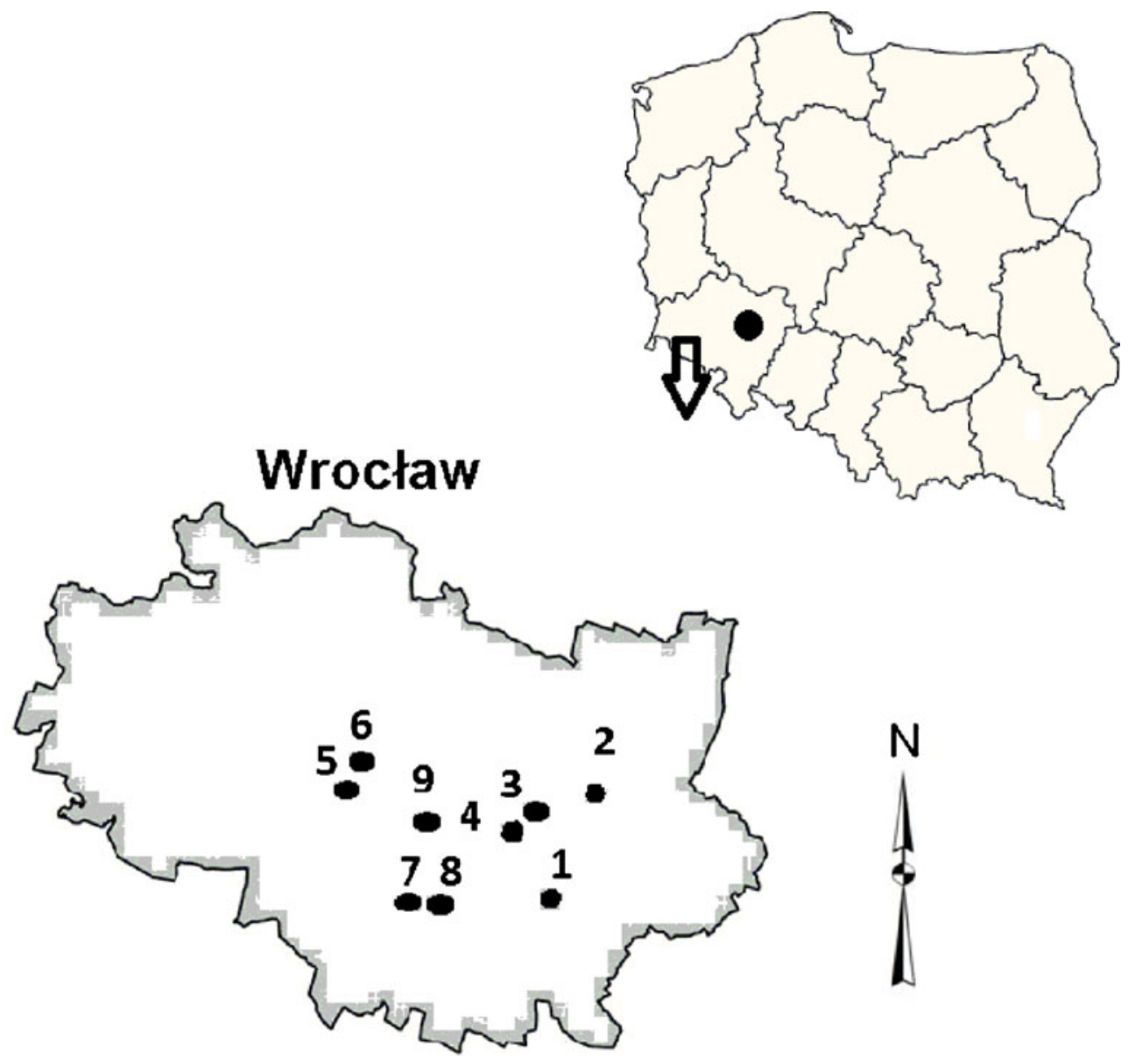

features allow to use their webs as an easy indication method that might work for most time of the year, which is an additional advantage in contrast to most bioindication methods, which can only be used in the season (e.g., water quality assessment based on benthic macroinvertebrates).

M. (Tegenaria) silvestris occurs mostly in forests; it can be also found under rocks, roots, and broken trees. In addition, $M$. silvestris inhabits ruins, tunnels, and caves; it is also found on the walls and even inside residential buildings (Roberts 1995).

Species $M$. ferruginea was named due to the red coloration of abdominal pattern. The spider lives in forests or near human habitations (Roberts 1995).

T. atrica males of this species are active from July to October; females, all year-round. They can be found on the rocks, in the basements, or forests. It is very common species (Roberts 1995).

T. agrestis occurs mainly under the rocks, among plants, landfills, often in the city centers, and often along the railway line. Its web is often based on plants. It is sometimes also found at homes and around (garages and walls of buildings) particularly in North America. Late summer and autumn are of the highest activity of this species (Harvey et al. 2002).

Basically, a web is made from proteins, but its composition also depends on the type of food caught by spider. Hence, the presence of various types of contaminants in insect bodies eaten by spiders may have an impact on their content in the body of predators and consequently may be present in their webs. Sometimes, insects can derive from a larger area than the hunting area of spider. However, research of Hose et al. (2002) showed that heavy metals settled on webs of studied spiders belonging to Cribellatae are not embedded inside the matrix of webs. Thus, we can presume that it might also be the case in other spider species which, like Agelenids, produce a nonsticky silk. The mechanism of accumulation alone and possible binding of PAH compounds with the web matrix is a separate issue which is also the subject of our research and will be presented in detail in a separate article. However, it is worth mentioning that Agelenids mostly feed on non-flying insects and other invertebrates which do not overcome a considerable distance as flying insects (some beetles, springtails, ants, and even earthworms; Foelix 1996; Nyffeller et al. 2001; Park and Moon 2002) which greatly reduces the risk of results falsification.

Samples collection

Only the newly constructed webs (collected after the removal of the old, where a spider was observed) after 60 days of 
exposure from the creation of new construction at all sites were chosen for studies to ensure the age of webs. To collect newly constructed webs, the previously chosen places were everyday visited and observed. Additionally, the methods of Champion de Crespigny et al. (2001) were used to prepare the spider webs for field deployment (i.e., standard size wooden frames settled by spiders in the laboratory and allowed to weave before deployment to the field). Webs were collected into the clean glass vials with sterile glass baguettes and transferred to the laboratory. Spider silk was controlled for potential confounding by ensuring similar web size and weight for all samplers with measurement of three-dimensional webs following the methodology given by Rybak (2007). Only webs of similar size and weight were used for analysis (Hose et al. 2002). All samples were weighed to the nearest $0.01 \mathrm{mg}$ and frozen for the analyses. Then, frozen webs were thawed and dried for $48 \mathrm{~h}$ at $70{ }^{\circ} \mathrm{C}$ and then weighed again (Hose et al. 2002).

\section{Laboratory analysis of spider web samples}

PAHs content was determined by gas chromatography GCMS with automatic batcher made by Perkin-Elmer AutoSystem XL capillary column ZB-35 (length 30 m; diameter $0.25 \mathrm{~mm}$; phase thickness $0.25 \mu \mathrm{m}$ ) carrying gas helium, injection $1 \mathrm{\mu l}$, and $120{ }^{\circ} \mathrm{C}(0 \mathrm{~min})-25{ }^{\circ} \mathrm{C} / \mathrm{min}-250{ }^{\circ} \mathrm{C}$ $(0 \mathrm{~min})-5{ }^{\circ} \mathrm{C} / \mathrm{min}-305(0 \mathrm{~min})-25{ }^{\circ} \mathrm{C} / \mathrm{min}-325{ }^{\circ} \mathrm{C}(8 \mathrm{~min})$ by using the absolute calibration for the PAH patterns. Method detection limit was $0.1 \mathrm{ng} / 50 \mu \mathrm{l}$ (i.e., for the tested solution of $0.002 \mu \mathrm{g} / \mathrm{ml}$ ). Web samples were weighed (approximately $0.06 \mathrm{~g}$ ) and then extracted using three portions $(1 \mathrm{ml})$ solution of methylene chloride and methanol (9: 1, v:v). After centrifuging extracts $(10,000 \mathrm{rpm})$, they were vaporized to dry residue in a nitrogen stream $\left(30^{\circ} \mathrm{C}\right)$. The residues were dissolved in $50 \mu \mathrm{l}$ methylene chloride and then analyzed. Identification of PAHs was based on the retention time and ultraviolet spectra of PAH standards. Alle samples were analyzed in duplicate. Qualitative and quantitative analysis of organic pollutants contained in the samples were made in the Chemistry Department of University of Wrocław and University of Environmental and Life Sciences in Wrocław.

The following 16 EPA PAH compounds: naphthalene, acenaphthylene, acenaphthene, fluorene, phenanthrene, anthracene, fluoranthene, pyrene, benzo $[a]$ anthracene, chrysene, benzo $[b]$ fluoranthene, benzo $[k]$ fluoranthene, benzo $[a]$ pyrene, indeno $[1,2,3-c, d]$ pyrene, dibenzo $[a, h]$ anthracene, and benzo $[g, h, i]$ perylene were analyzed after a calibration curve has been performed for each compound using a mixture of external standard 16 PAHs at known concentrations.

To evaluate the extraction efficiency, the strict quantity of 16 PAHs mixture was introduced artificially into blank samples (blank). The results are presented in Table 2. Obtained recovery factors for each compound were included in the results.
Table 2 Validity check for chemical methods. Recovery rates and standard deviation of the corresponding PAHs in the analyzed web samples $(n=6)$

\begin{tabular}{llr}
\hline & Recovery factor $[\%]$ & SD \\
\hline Naphthalene & 75.3 & 12.4 \\
Acenaphthylene & 89.5 & 5.3 \\
Acenaphthene & 98.7 & 8.9 \\
Fluorene & 99.4 & 12.1 \\
Phenanthrene & 87.3 & 13.4 \\
Anthracene & 88.7 & 6.2 \\
Fluoranthene & 98.1 & 16.1 \\
Pyrene & 91 & 8.2 \\
Benzo $[a]$ anthracene & 89.2 & 14.2 \\
Chrysene & 93.1 & 12.5 \\
Benzo $[b]$ fluoranthene & 95.3 & 7.8 \\
Benzo[ $k]$ fluoranthene & 96.4 & 6.5 \\
Benzo $[a]$ pyrene & 90.1 & 9.9 \\
Indeno $[1,2,3-c, d]$ pyrene & 99.6 & 15.7 \\
Dibenzo $[a, h]$ anthracene & 95.4 & 11.8 \\
Benzo $[g, h, i]$ perylene & 82.7 & 12.5 \\
\hline
\end{tabular}

Statistical analysis

The STATISTICA ${ }^{\circledR}$ package was used for all calculations. The amount of PAHs accumulated at studied sites was compared using nonparametric Kruskal-Wallis and Mann-Whitney $U$ tests. We tested the hypothesis of nonsignificant difference between the vehicle and railway traffic sites $(3,5,6,7$, and 9) and reference sites (1 and 2). In order to check intraspecific $(n=12)$ and interspecific variability $(n=14)$, one-way ANOVA was performed. Data were checked for normal distribution (Shapiro-Wilk W test) and homogeneity of variance (Levene's test). Spearman correlation coefficient was calculated for the correlation among PAH concentrations in web samples according to the distance from the emission sources. Tests of significance were made at $95 \%$ confidence level.

PCA was performed for vehicle traffic and railway traffic sites protected from the influence of weather conditions (sites 3 , 5,6 , and 9) and also for chosen vehicle traffic sites separately (sites 3 and 4) in order to determine the structure of the relationship between concentrations of compounds measured in the webs and, on this basis, potential sources of pollution were identified. Due to the similarity in webs construction (similar density and type of construction) and lack of significant differences regarding to interspecific and intraspecific variability of samples, the concentrations of PAHs recorded for all four species were compared together by performing the PCA. Other comparison tests were done within the same genera.

PCA was used to reduce the set of original variables and to extract a small number of principal components to analyze the relationship among observed variables. It should be noted that 
the assumptions of PCA were met (continuity of the variables and the number of elements observed should be greater than the number of original variables). All factors with eigenvalues over 1 were extracted according to KMO and Barlett's test of sphericity and were rotated using Varimax method.

\section{Results}

General PAHs trends and profiles

All 16 EPA PAHs were detected at all sites. Benzo $[a]$ anthracene was consistently the most concentrated PAH and represented $18.56 \%$ of the total contamination, followed by fluoranthene (12.7\%), pyrene (11.5\%), chrysene (10.2), and benzo[ $a]$ pyrene $(9.7 \%)$. The concentration of the 16 EPA PAHs varied from $279 \mathrm{ng} / \mathrm{g}$ (dry weight) assessed at reference site 1 to $9,155 \mathrm{ng} / \mathrm{g}$ (dw) at vehicle traffic site 7 (arterial surface road). The mean concentrations of PAHs identified in webs of the two genera Tegenaria and Malthonica are given in Tables 3 and 4. The trends of the total PAH contamination can be seen in Fig. 2 and Table 5. The compounds were grouped according to the number of aromatic rings present in their structures with the purpose of establishing a relationship between volatility of the compounds and the sampling sites (Fig. 2). For all sites, the presence of the most volatile two-ring compounds was very low and corresponded from 0 to $3.86 \%$ and three- and four-ring compounds (higher or medium volatility) were found mainly at vehicle traffic sites (sites 3, 4, 7, and 8) and at reference site 1 (municipal water supply works) as well. Regarding the five- and six-ring compounds of lower volatility with high carcinogenic potential (Rodriguez et al. 2012) were found at reference sites 1 and 2, two vehicle traffic sites (sites 7 and 8), and railway traffic sites (sites 5 and 6). For all sites, five-ring PAHs have the highest mean percentage (from 17 to $55 \%$ ); the second highest percentage was calculated for four-ring compounds (from 28 to $54 \%$ ). In order to differentiate combustion and petroleum sources PAHs of molecular mass, 178 (Phen and Anth) and 202 (Flua and Pyr) are used according to Orecchio et al. (2008) (Table 5). The majority of sites showed a very low petrogenic tendencies in the Phen/Anth ratio between 0.04 and 6.6 and both pyrogenic and petrogenic tendencies in the Flua/Pyr ratio: from 0.4 to 8.1. Vehicle traffic sites $(7,8$, and 9) and railway traffic sites (5 and 6) revealed highest petrogenic tendencies in comparison to the rest of the studied sites. One of the vehicle traffic sites (site 7: arterial surface road) additionally showed a very strong petrogenic influence in the Phen/Anth ratio (41).

\section{Spider species web comparison}

Specimens of $T$. atrica ( $n=12$, site 6$)$ chosen to check intraspecific variability were collected at the same site. It was

Table 3 Mean concentrations and standard deviation of PAHs at selected sites in 2011; the samples were collected after 60 days of exposure for genus Malthonica. Concentrations and SD are given in nanogram per gram dry weight

\begin{tabular}{|c|c|c|c|c|c|c|}
\hline $\mathrm{PAH}[\mathrm{ng} / \mathrm{g}]$ & Site no. 1 reference site & Site no. 2 reference site & $\begin{array}{l}\text { Site no. } 3 \\
\text { Parking I }\end{array}$ & $\begin{array}{l}\text { Site no. } 4 \\
\text { Parking II }\end{array}$ & $\begin{array}{l}\text { Site no } .7 \\
\text { Surface road I }\end{array}$ & $\begin{array}{l}\text { Site no. } 8 \\
\text { Surface road II }\end{array}$ \\
\hline Naphthalene & L. d. & $15.9 \pm 2.1$ & $3.6 \pm 1.08$ & $1.9 \pm 0.8$ & $13.01 \pm 3.05^{*}$ & $1.2 \pm 0.2$ \\
\hline Acenaphthylene & L. d. & L. d. & L. $d$ & L. d & $65.06 \pm 3.8$ & $25.9 \pm 2.5$ \\
\hline Acenaphthene & L. d. & L. d. & $91.1 \pm 5.2$ & L. d. & $13.01 \pm 1.9$ & L. d. \\
\hline Fluorene & L. d. & $15.2 \pm 6.4$ & $191.1 \pm 11$ & L. d. & $19.5 \pm 6$ & L. d. \\
\hline Phenanthrene & L. d. & $58.7 \pm 12.2$ & $331.6 \pm 16.6^{*}$ & $140.9 \pm 35.8$ & $227.7 \pm 33.9$ & $20.5 \pm 1.9$ \\
\hline Anthracene & L. d. & $23.2 \pm 8.9$ & $80.6 \pm 12.5^{*}$ & $65.1 \pm 12.4$ & $551.3 \pm 49.9 *$ & $451.4 \pm 16$ \\
\hline Fluoranthene & $86.6 \pm 5.2$ & $541.5 \pm 27.2$ & $570.9 \pm 54.9^{*}$ & $144.7 \pm 9$ & $1,035.8 \pm 26.4^{*}$ & $312.06 \pm 25.2$ \\
\hline Pyrene & $64.9 \pm 2.2$ & $78.8 \pm 9$ & $70.2 \pm 12.4 *$ & $29.8 \pm 12$ & $1,014.3 \pm 37.01 *$ & $532.1 \pm 30.3$ \\
\hline Benz $[a]$ anthracene & L. d. & $121.3 \pm 7$ & $141.8 \pm 14.6^{*}$ & $74.6 \pm 12.3$ & $2,565.4 \pm 25.3 *$ & $1,245.1 \pm 63.4$ \\
\hline Chrysene & $33.0 \pm 2.1$ & $56.3 \pm 6.9$ & $189.1 \pm 10.7^{*}$ & $119.4 \pm 6.9$ & $764.8 \pm 22.9$ & $709.8 \pm 14.06$ \\
\hline Benzo $[b]$ fluoranthene & L. d. & $57.2 \pm 2.4$ & $307.3 \pm 41.03 *$ & $134.3 \pm 25.9$ & $307.7 \pm 13.2$ & $121.6 \pm 11.6$ \\
\hline Benzo $[k]$ fluoranthene & L. d. & $70.1 \pm 3.6$ & L. d. & L. d. & L. d. & L. d \\
\hline Benzo $[a]$ pyrene & $94.5 \pm 7.3$ & $78.7 \pm 9.5$ & $141.8 \pm 23.04 *$ & L. d. & $906.3 \pm 19.8^{*}$ & $400.8 \pm 14.7$ \\
\hline Indeno $[1,2,3-c, d]$ pyrene & L. d. & L. d & $330.9 \pm 26.9^{*}$ & $179.1 \pm 21.4$ & $653.2 \pm 15.3^{*}$ & $381.2 \pm 35.7$ \\
\hline Dibenz $[a, h]$ anthracene & L. d. & $69.1 \pm 2.6$ & L. d. & L. d. & $306.6 \pm 26.2^{*}$ & $205.8 \pm 9.1$ \\
\hline Benzo $[g, h, i]$ perylene & L. d. & $673.04 \pm 98.4$ & L. d. & L. d & $711.9 \pm 40.9 *$ & $227.5 \pm 39.3$ \\
\hline Sum of PAHs & $279.08 \pm 16.8$ & $1,859.1 \pm 197.2$ & $2,450.3 \pm 230.1$ & $890.06 \pm 136.5$ & $9,155.5 \pm 325.6$ & $4,635.99 \pm 264.02$ \\
\hline
\end{tabular}

L. $d$. below detection limit

${ }^{*} p<0.05$ (the values are statistically significant between sites 1 and 3 (asterisk at site 3, genus Malthonica) and site 3 and 7 (asterisk at site 7 , genus Malthonica); $n=5$ ) 
Table 4 Mean concentrations and standard deviation of 16 EPA PAHs at selected sites in 2011; the samples were collected after 60 days of exposure for genus Tegenaria. Concentrations and $\mathrm{SD}$ are given in nanogram per gram dry weight

\section{L. $d$. below detection limit}

${ }^{*} p<0.05$ (the values are statistically significant between sites 1 and 5, 6, and 9 (asterisk at sites 5, 6, and 9, genus Tegenaria); $n=5$ )

\begin{tabular}{llll}
\hline PAHs[ng/g] & site no. 5 railway viaduct & site no.6 railway viaduct & site no. 9 road tunnel \\
\hline Naphthalene & $18 \pm 3.1$ & $14.9 \pm 3.1$ & L. d. \\
Acenaphthylene & $18.9 \pm 3.2^{*}$ & $3.4 \pm 0.3^{*}$ & $16.7 \pm 1.4^{*}$ \\
Acenaphthene & $14.4 \pm 1.51$ & $7.4 \pm 1.4$ & L. d. \\
Fluorene & $35.1 \pm 2.09$ & $26.1 \pm 2.2$ & L. d. \\
Phenanthrene & $286.4 \pm 9.09^{*}$ & $34.4 \pm 9.9^{*}$ & $150.7 \pm 4.6^{*}$ \\
Anthracene & $43.5 \pm 5.7^{*}$ & $110.1 \pm 6.7^{*}$ & $165.1 \pm 13.8^{*}$ \\
Fluoranthene & $343.4 \pm 29.9^{*}$ & $114.9 \pm 2.9^{*}$ & $766.1 \pm 23.6^{*}$ \\
Pyrene & $380.1 \pm 25.5^{*}$ & $240.02 \pm 25.5^{*}$ & $1154.9 \pm 48.5^{*}$ \\
Benz[$[a]$ anthracene & $515.4 \pm 9.4^{*}$ & $245.5 \pm 12.2^{*}$ & $787.3 \pm 51.6^{*}$ \\
Chrysene & $386.3 \pm 10^{*}$ & $191.9 \pm 15.3^{*}$ & $684.5 \pm 21.06^{*}$ \\
Benzo[$[b]$ fluoranthene & $100.4 \pm 11.6^{*}$ & $440.7 \pm 31.03^{*}$ & $350.3 \pm 6.6^{*}$ \\
Benzo[ $k]$ fluoranthene & $123.4 \pm 13.9$ & L. d. & L. d. \\
Benzo[ $a]$ pyrene & $451.7 \pm 6.05^{*}$ & $313.6 \pm 1.5^{*}$ & $607.03 \pm 5.1^{*}$ \\
Indeno[ $1,2,3-c, d]$ pyrene & $145.7 \pm 3.8^{*}$ & $74.5 \pm 5.07^{*}$ & $396.8 \pm 36.9^{*}$ \\
Dibenz $[a, h]$ anthracene & $315.9 \pm 6.09^{*}$ & $170.9 \pm 8.6^{*}$ & $67.02 \pm 5.7^{*}$ \\
Benzo[g,h,i]perylene & $740.9 \pm 5.4^{*}$ & $38.8 \pm 4.7^{*}$ & $314.08 \pm 8.5^{*}$ \\
Sum of PAHs & $3920.8 \pm 146.4$ & $2027.34 \pm 130.49$ & $5460.8 \pm 227.6$ \\
\hline
\end{tabular}

found that all studied specimens display the same entrapment abilities among themselves as significant differences were not observed when performing one-way ANOVA $(p>0.05)$. We also compared the results obtained for webs of four studied species (M. silvestris, M. ferruginea, T. agrestis, and $T$. atrica) for the site $7(n=14)$ to check interspecific variability to get similar results (one-way ANOVA; $p>0.05$ ). The obtained results are in line with our presumptions as specific structure of spider web is characteristic for the whole family of spiders not for particular individuals or species. In the previous research of Hose et al. (2002) and Xiao-li et al. (2006), the authors studied four species deriving from different spider families and significant differences were observed. More detailed results will be presented and described in the future
Fig. 2 Contribution (\%) of two-, three-, four-, five-, and six-ring PAHs to total sum at studied sites

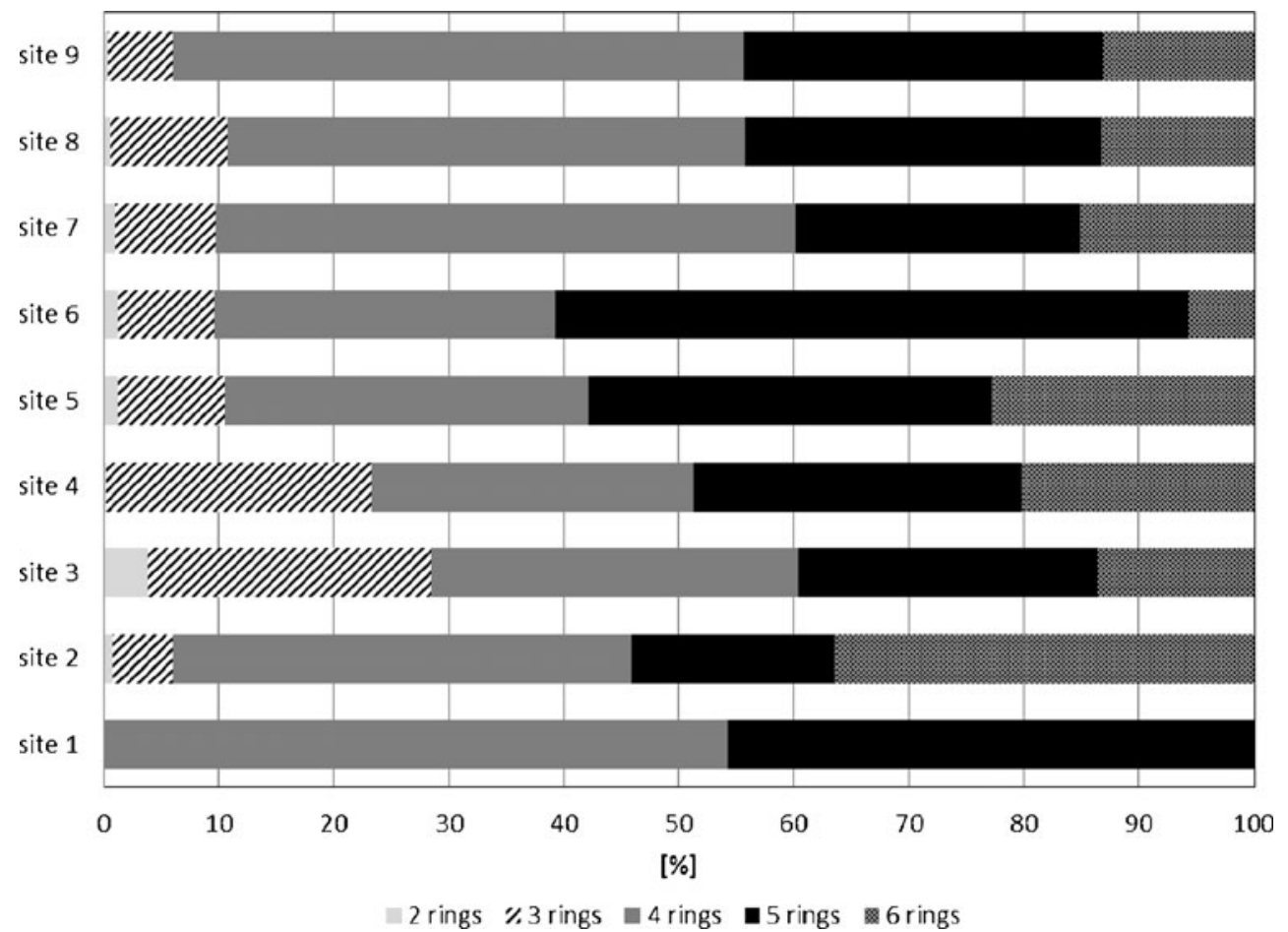


Table 5 Molecular ratios calculated for nine sites of phenanthrene/anthracene (Phen/Anth) and fluoranthene/pyrene (Flua/Pyr)

\begin{tabular}{lcc}
\hline Site & $\begin{array}{c}\text { Phen/ } \\
\text { Anth }\end{array}$ & $\begin{array}{l}\text { Flua/ } \\
\text { Pyr }\end{array}$ \\
\hline $\begin{array}{l}\text { Site no. 1 -reference site: municipal water supply } \\
\quad \text { works }\end{array}$ & - & 1.3 \\
Site no. 2-reference site: urban residential & 2.5 & 6.8 \\
Site no. 3 - underground parking I & 4.1 & 8.1 \\
Site no. 4 - underground parking II & 2.3 & 4.8 \\
Site no. 5-railway viaduct & 6.6 & 0.9 \\
Site no. 6 - second railway viaduct & 0.3 & 0.4 \\
Site no. 7-arterial surface road I & 41.1 & 1.02 \\
Site no. 8 - arterial surface road II & 0.04 & 0.58 \\
Site no. 9- road tunnel & 0.9 & 0.66 \\
\hline
\end{tabular}

paper discussing interspecific variability among different spider families.

\section{Inter-site differences in PAHs}

Analysis with the use of Kruskal-Wallis test and Mann-Whitney $U$ test revealed significant differences for most PAHs in samples (genus Malthonica) between the reference site 1 and two vehicle traffic sites: site 3 (underground parking) with a few exceptions (naphthalene, acenaphthylene, acenaphthene, benzo $[k]$ fluoranthene, dibenzo $[a, h]$ anthracene, and benzo $[g, h, i]$ perylene) and site 7 (arterial surface road) with the exception of acenaphthylene, acenaphthene, fluorene, chrysene, benzo $[b]$ fluoranthene, and benzo $[k]$ fluoranthene $(p<0.05$, see Table 3$)$. A significant difference was not observed between reference site 2 and two vehicle traffic sites 3 (underground parking) 7 (arterial surface road) (genus Malthonica). Most samples of PAHs (genus Tegenaria) differed significantly among the reference site 1 and railway traffic sites (sites 5 and 6) and vehicle traffic site 9 (road tunnel) with a few exceptions (naphthalene, acenaphthylene, fluorene, and benzo[ $k]$ fluoranthene) $(p<0.05$, see Table 4$)$.

Sites located closer to emission source (site 3 : underground parking and site 7 : arterial surface road) revealed significantly higher concentrations than sites placed a bit away (sites 4 and 8). In all cases, webs of $M$. ferruginea were investigated and we found significant differences at sites differing with the distance from emission sources $(p<0.05$, Spearman's rho was 0.88 for sites 3 and 4 and 0.92 for sites 7 and 8 ).

\section{PCA analysis}

PCA analysis was performed together for vehicle and railway traffic sites located in the parking, two railway viaducts, and in road tunnel $(3,5,6$, and 9). In order to increase stability and readability of the analysis of four compounds (acenaphthylene, benzo $[k]$ fluoranthene, dibenzo $[a, h]$ anthracene, and benzo $[g, h, i]$ perylene) were excluded from the analysis because they have been identified in small quantities or below detection limit. Figure $3 \mathrm{a}, \mathrm{b}$ presents three components (cumulative percentage of variance explained by the three components: $86.7 \%$ ). The rotated factors of normalized 12 PAHs identified at vehicle and railway traffic sites are presented in Table 6. Factor 1, which explains $47.9 \%$ of the total variance, is dominated by anthracene, fluoranthene, and indeno[ $[1,2,3-c, d]$ pyrene. The factor 2 , which explains $25.2 \%$, is dominated by acenaphthene, fluorene, pyrene, benzo $[a]$ anthracene, chrysene, and benzo $[a]$ pyrene. The third factor, contributing $13.6 \%$ of total variance, is highly weighed by phenanthrene.

We did PCA also for sites 3 and 4 (parking) in order to exclude possible compounds (sites 5, 6, and 9) that may derive from railway transport. In this analysis, two components were defined explaining $86.5 \%$ of cumulative percentage of variance. The four compounds were excluded from the analysis which had been eliminated before (Fig. 3c). The rotated factors of normalized 12 PAHs identified at two railway traffic sites are presented in Table 7. Factor 1, which explains $73.7 \%$ of the total variance, is dominated by fluorene, phenanthrene, fluoranthene, benzo $[a]$ anthracene, chrysene, benzo $[b]$ fluoranthene, benzo $[a]$ pyrene, and indeno[ $[1,2,3-c, d]$ pyrene. Factor 2, which explains $12.7 \%$, is highly weighed by naphthalene, acenaphthene, and pyrene.

When we consolidated results for sites 3, 4 (parking), and 9 (tunnel), the same results were obtained for the PCA analysis as in calculations done for vehicle and railway traffic sites (sites 3, 5, 5, and 9). In turn, the performance of the analysis only for site 9 was not possible due to the limited number of data.

\section{Discussion}

\section{Differences in PAHs among studied sites}

The webs exposed to the road traffic emissions also showed a significantly higher concentrations of PAHs than the webs collected at one of the reference site (site 1 municipal water supply works) (Tables 3 and 4). Reference site 2 (urban residential), although situated in a quiet area with a low traffic in the eastern part of the city of Wrocław, was characterized by the increased concentrations of certain PAHs, which could be related with a predominance of the west and south winds (Dubicki et al. 2002) and with the existing common habit of leaves burning in backyards (in the spring and autumn) and also with very popular summer activity, barbecue organizing, both contribute to an increased amount of PAHs in the atmosphere in this part of the city (Wojewódzki Inspektorat Ochrony Środowiska 2012). The significant differences were found at sites of different distance from emission sources 

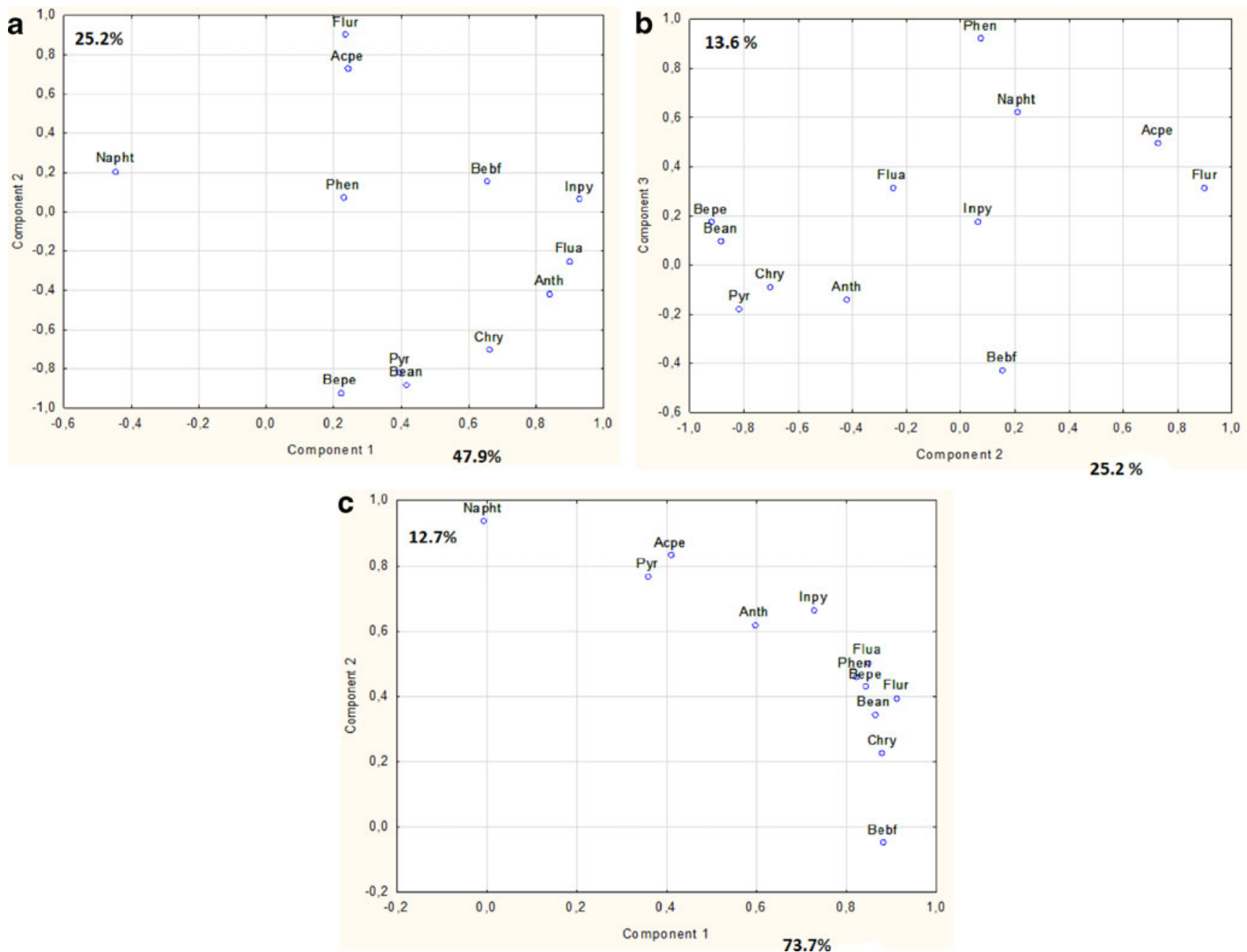

Fig. 3 a PCA analysis for sites 3, 5, 6, and 9 (tunnel, viaducts, and parking) excluding Acpy, Bekf, Dibe, and Bepy. Cumulative percentage of variation explained by three components: $86.78 \%$. Webs of species Malthonica (site 3) and Tegenaria (sites 5, 6, and 9) were used. Napht naphthalene, Acpy acenaphthylene, Acpe acenaphthene, Flur fluorene, Phen phenanthrene, Anth anthracene, Flua fluoranthene, Pyr pyrene, Bean benzo $[a]$ anthracene, Chry chrysene, Bebf benzo $[b]$ fluoranthene,

which is in line with our presumptions and other findings regarding the influence and the distance from emission source on pollution level (Rodriguez et al. 2012). Generally, the results showed a positive correlation between PAHs content and distance close to the road indicating the contribution of pollution emissions from the road. Such results indicate that Agelenids are efficient indicators of PAHs.

Comparisons between spider webs and other matrices

As accumulative properties of webs concerning PAHs have not been analyzed yet, we cannot compare our findings with any other studies. But, in the pilot studies carried out in the tunnel in Austria on mosses (species: Hylocomium splendens) in areas with heavy traffic, high values of PAHs were also
Bekf benzo $[k]$ fluoranthene, Bepe benzo $[a]$ pyrene, Inpy indeno[1,2,3$c, d]$ pyrene, Dibe dibenzo $[a, h]$ anthracene, Bepy benzo $[g, h, i]$ perylene. b PCA analysis for sites 3, 5, 6, and 9 (tunnel, viaducts, and parking). Components 2 and 3. c PCA analysis for sites 3 and 4 (parking) excluding Acpy, Bekf, Dibe, and Bepy. Cumulative percentage of variation explained by two components: $86.52 \%$. Webs of species $M$. ferruginea were used

obtained (Zechmeister et al. 2006). The authors in this work present the specific advantages of using bioindicators in the tunnel. They believe that road traffic pollutants persist there longer and are present in higher concentrations than in the open area near roads with heavy traffic. The fact that gases and dust particles persist for much longer in tunnels before they mix with the outside air was confirmed by numerous studies and experiments carried out in tunnels and also on multi-level car parks (Rogula et al. 2007; Suchecki 2006). In the open area, some of these contaminants might be removed as a result of rain falling and wind blowing, which is simply impossible in the tunnel. Hence, our study carried out in the parking and in the tunnel, like Zechmeister et al. (2006) studies, should also allow to predict (or compare with previous findings) compounds associated with traffic pollution. In our research, 
Table 6 Rotated principal component matrix of PAHs for sites. Rotation method VARIMAX with Keiser normalization. Bold loadings $>0.70$

\begin{tabular}{lccc}
\hline PAHs & Component 1 & Component 2 & Component 3 \\
\hline Naphthalene & -0.44 & 0.2 & 0.62 \\
Acenaphthene & 0.24 & 0.72 & 0.5 \\
Fluorene & 0.23 & 0.9 & 0.31 \\
Phenanthrene & 0.22 & 0.07 & 0.92 \\
Anthracene & 0.83 & -0.41 & -0.14 \\
Fluoranthene & 0.89 & -0.25 & 0.31 \\
Pyrene & 0.4 & 0.81 & -0.17 \\
Benz $[a]$ anthracene & 0.41 & 0.88 & 0.09 \\
Chrysene & 0.66 & -0.7 & -0.08 \\
Benzo[ $b]$ fluoranthene & 0.65 & 0.15 & -0.42 \\
Benzo[ $a$ ]pyrene & 0.22 & -0.92 & 0.17 \\
Indeno[ $[1,2,3-c, d]$ pyrene & 0.92 & 0.06 & 0.17 \\
Variance, \% & 47.9 & 25.2 & 13.6 \\
\hline
\end{tabular}

all selected sites were protected against washout (webs were collected from places sheltered from the rain). Spiders instinctively inhabit a shaded and protected against accidental damage places.

The highest pollution was reported at arterial surface road (site 7) (the sum of PAHs $=9,155.56 \pm 325.62 \mathrm{ng} / \mathrm{g}$ ), but not in the road tunnel (site 9) or railway viaducts (sites 5 and 6) or in the underground parking (site 3) (Tables 3 and 4). Our road tunnel and railway viaducts were not relatively long length (from 20 to $90 \mathrm{~m}$ ) even when compared to road tunnel studied by Zechmeister et al. (2006) which was much longer (several hundred meters), offering greater isolation from factors affecting pollutant dispersion and reactivity and additionally preventing the entrance of pollutants from adjacent streets and houses via its opening. Our results confirm data obtained

Table 7 Rotated component matrix of PAHs for sites 3 and 4. Rotation method VARIMAX with Keiser normalization. Bold loadings $>0.70$

\begin{tabular}{lll}
\hline PAHs & Component 1 & Component 2 \\
\hline Naphthalene & -0.007 & 0.93 \\
Acenaphthene & 0.4 & 0.83 \\
Fluorene & 0.91 & 0.4 \\
Phenanthrene & 0.82 & 0.46 \\
Anthracene & 0.6 & 0.61 \\
Fluoranthene & 0.84 & 0.5 \\
Pyrene & 0.36 & 0.76 \\
Benz[ $a$ ]anthracene & 0.86 & 0.34 \\
Chrysene & 0.87 & 0.22 \\
Benzo[$[b]$ fluoranthene & 0.88 & $-0,05$ \\
Benzo $[a]$ pyrene & 0.84 & 0.42 \\
Indeno $[1,2,3-c, d]$ pyrene & 0.72 & 0.66 \\
Variance, $\%$ & 73.74 & 12.78 \\
\hline
\end{tabular}

by the Regional Inspectorate for Environmental Protection (report, Wojewódzki Inspektorat Ochrony Środowiska 2012), which also have recorded the highest concentrations of heavy metals and selected PAH compounds in this area (site 7) of Wroclaw (although they did not compare the obtained results with the sites described in our work). The results are directly connected with the number of cars passing (data given in Table 1), which is very large, if not the largest, in the city (report, Wojewódzki Inspektorat Ochrony Środowiska 2012).

The total concentrations of PAH recorded in our study (Tables 3 and 4) were compared with studies carried out in Warsaw by Orliński (2002) and in Austria by Zechmeister et al. (2006) within a period of 4 weeks (in both cases). Only the results obtained by Zechmeister et al. (2006), where the sum of the PAHs was $4,100 \mathrm{ng} / \mathrm{g}$, were somehow similar to ours (coronene was not included in our analyses). Spider webs were exposed in the experiment for 60 days; hence, the obtained results were more than two times higher (site 7 arterial surface road). Thus, we can say that our results reported for arterial surface road (site 7) are comparable with the results of the experiment carried out in the road tunnel done by Zechmeister et al. (2006). The sum of total PAHs was less higher in road tunnel ( site 9: 5,460.85 $\pm 227.59 \mathrm{ng} / \mathrm{g}$ ), but right after the site 7 (arterial surface road), more than twice lower in the railway viaduct (site 5: 3,920.82 $\pm 146.45 \mathrm{ng} / \mathrm{g}$ ) and finally several times lower at the underground parking (site 3: $2,450.335 \pm 230.13 \mathrm{ng} / \mathrm{g})$.

\section{PAH source assessment}

The predominance of high molecular weight PAHs is connected with such sources as combustion processes and traffic and industrial activities (Ratola et al. 2012). Probably, the main PAH uptake onto the silk matrix is by direct deposition processes unlike in case of pine needles where the main uptake is gaseous absorption realized by the waxy layer of the needles (Ratola et al. 2012). This is probably the explanation why benzo $[a]$ anthracene and other four- and five-ring compounds predominated in this study. Probably, this is also an evidence of limitation of sampling method (since sampling is restricted to particle phase PAH, and thus, necessarily poorer sampling of light species that are predominately found partitioned to vapor phase).

Concerning phenanthrene/anthracene and fluoranthene/ pyrene ratios, the variety of PAH sources possibly affect the investigated sites, but as suggested by (Table 5) Ratola et al. (2012), all this ratios must be considered with caution, especially that these petrogenic/pyrogenic rules were set from analysis in sediments. In Ratola et al. (2012) studies, results obtained by the authors brought also difficulties in distinguishing between pyrogenic and petrogenic sources of PAHs in pine needles. The authors suggest that anthracene is not very thermodynamically stable compared to phenanthrene; thus, the high ratio of Phen/ Anth may be a consequence of faster Anth decay. In our studies, 
only one site (site 7; arterial surface road) revealed vary high ratio of Phen/Anth showing very strong petrogenic influence.

Highest PAH concentrations were measured for phenanthrene, pyrene, and fluoranthene for vehicle traffic sites (site 7: arterial surface road and site 9: road tunnel) and for fluoranthene at the underground parking (sites 3 and 4) (Tables 3 and 4). All the abovementioned three compounds are well-known pollution markers (Harrison et al. 2003). In addition, a high concentration of benzo[ $a]$ anthracene was also recorded for vehicle traffic sites (site 7: arterial surface road and site 9: road tunnel). A high concentration of indeno $[1,2,3-c, d]$ pyrene was measured also for vehicle traffic sites (site 3: parking and site 7: arterial surface road). Both compounds were proposed by Zechmeister et al. (2006) as a potentially good traffic road emission indicator. We also found highest concentrations of benzo[ $a$ ]pyrene for vehicle traffic sites (site 7: arterial surface road and site 9: road tunnel). This compound is the most known traffic road emission related compound (Esen et al. 2008; Zuo et al. 2007). High concentrations of fluoranthene, pyrene, benzo[a]pyrene, and benzo $[a]$ anthracene (considered to be the markers of traffic pollutants) were also measured for railway traffic sites (particularly site 5, but also site 6) which suggest that pollution recorded at these sites could have a similar source, thus, could be associated with road traffic emissions not with specific rail pollutants.

PCA multivariate analysis performed together for railway and vehicle traffic sites revealed three significant components (potential sources of PAHs) (Fig. 3, Tables 6 and 7). The first factor is dominated by anthracene, fluoranthene and indeno $[1,2,3-c, d]$ pyrene. Two fist compounds are more volatile, but Inpy, high molecular weight six-ring compound, is found in both diesel and gas engine emissions and was revealed as the indicator of emissions of vehicular transportations (Esen et al. 2008, Zuo et al. 2007). The second factor includes acenaphthene, fluorene, pyrene, benzo $[a]$ anthracene, chrysene, and benzo $[a]$ pyrene. Pyrene and benzo $[a]$ pyrene are typical markers of coal combustion and can be a tracer of auto emissions (Esen et al. 2008; Liu et al. 2009); the presence of chrysene could indicate the dominance of diesel emissions (Bourotte et al. 2005); therefore, this factor is selected to represent the traffic-related source of PAHs. The third factor is highly weighed only by phenanthrene which is also a marker of coal combustion (Liu et al. 2009). In Wrocław, as in Poland in general, coal is still an important energy source and it is used widely for domestic and industrial purposes (Wojewódzki Inspektorat Ochrony Środowiska 2012).

Two sites were located inside the railway viaducts, which could have an impact on the type of pollutants identified there. The organic pollution associated with rail (such as rail wear and the brakes usage, applying herbicides, leaks from machinery and aggregates, the penetration of waterproofing underlayment into the soil, storage and transport of fuels, and the penetration of the coal ash used to gravel paths) can also affect the results; therefore, the area of underground parking (sites 3 and 4) was employed separately in PCA analysis (Fig. 3c, Table 7). It revealed the two important components. Factor 1 was predominately composed of fluorene, phenanthrene, fluoranthene, benzo $[a]$ anthracene, chrysene, benzo $[b]$ fluoranthene, benzo $[a]$ pyrene, and indeno[ $[1,2,3-c, d]$ pyrene. The source of this factor represents and appears to be road (diesel and gasoline) emissions. Factor 2 was dominated by naphthalene, acenaphthene, and pyrene. Naphthalene and acenaphthene, due to their high volatility, exhibit a weak interaction, resulting in bounding difficulties to any fraction of dust particles, and thus, with threads of webs, which probably explains the small concentrations of these compounds registered. The accumulation patterns of two-ring naphthalene differ from other identified PAH compounds, perhaps this has to do with a high volatility of this compound and its distribution in the gaseous phase (Wingfors et al. 2001; Zechmeister et al. 2006); thus, this compound should be excluded from such type of studies because such analysis beyond confirming very low levels registered in particle phase will be not useful. These are probably the reasons explaining the clustering of these compounds as a separate component.

What is more, Ortega-Jiminez and Dudley (2013) studied electrical attraction of prey and water droplets to spider webs. They found that capture success of spider webs has been associated with their microstructure, ornamentation, and windinduced vibrations. The web was negatively charged, but prey and water droplets tend to be positively charged, smaller droplets were more positively charged due to their greater relative surface area, and were more attracted to spider webs (OrtegaJiminez and Dudley 2013) which suggest that dust particles can also behave in the same way on the webs as droplets of water.

\section{Spider webs as environmental indicators}

Although significant differences were found at sites of different distance from emission sources and among reference site and vehicle and railway traffic sites, which demonstrates a successful use of webs when assessing the level of air contamination, some limitations of the method were also revealed. Probably, PAHs uptake is done directly by the deposition processes; thus, the high molecular weight compounds could be mainly measured with the use of spider web. More volatile, lighter molecular weight species are probably lost during or after sampling. What is more, applying webs over long time sampling period for the monitoring of air pollution can cause problems with the right interpretation of the obtained results as sampling artifacts and multiple contributing source types or events can influence and challenge source apportionment.

\section{Conclusions}

Our pilot studies prove that spider webs of Agelenidae family are good for indication of road traffic emissions. Research has 
shown their ability to immobilization of some PAH compounds (of high molecular weight mainly) previously defined as markers of traffic contamination (benzo[ $[a]$ pyrene, pyrene, fluoranthene, and phenanthrene) and others such as benzo $[a]$ anthracene and indeno $[1,2,3-c, d]$ pyrene that may also serve this role. The use of spider webs is cost-efficient and more practical than the application of many flora-based bioindicators such as mosses or lichens with potentially more reliable results due to better control of confounding made possible by selective habitat preferences of studied spiders. Research can be carried out all-yearround (e.g., it is possible to breed spiders under laboratory conditions and then exposing their webs in the field). Studies are quick and easy-to-apply, and the effects are comparable to these obtained by using a typical air pollutant field sampling equipment which requires a special conditions for its installation.

Acknowledgments The work was financed by the Minister of Science and of Higher Education, research project no. N N305 096639.

Open Access This article is distributed under the terms of the Creative Commons Attribution License which permits any use, distribution, and reproduction in any medium, provided the original author(s) and the source are credited.

\section{References}

Bourotte C, Forti MC, Taniguchi S, Caruso M, Lotufo PA (2005) A wintertime study of PAHs in fine and coarse aerosols in Sao Paulo City, Brazil. Atmos Environ 39:3799-3811

Champion de Crespigny FE, Herberstein ME, Elgar MA (2001) Food catching in orb web spiders (Araneae: Araneiodaea). Naturwissenschaften 88:42-45

De Nicola F, Lancelotti C, Prati VM, Maisto G, Alfani A (2011) Biomonitoring of PAHs by using Quercus ilex leaves: source diagnostic and toxicity assessment. Atmos Environ 45:1428-1433

Dubicki A, Dubicka M, Szymanowski M (2002) Wrocław climate In Dubicki A. (ed) Środowisko Wrocławia - Informator 2002, Dolnośląska Fundacja Ekorozwoju, Wrocław, pp. 9-25 (in Polish)

Esen F, Tasdemir Y, Vardar N (2008) Atmospheric concentrations of PAHs, their possible sources and gas-to-particle partitioning at a residential site of Bursa. Atmos Res 88:243-255

Foelix RF (1996) Biology of spiders. Oxford University, New York

Harrison RM, Tiling R, Callen Romero MS, Harrad S, Jarvis K (2003) A study of trace metals and polycyclic aromatic hydrocarbons in the roadside environment. Atmos Environ 37:2391-2402

Harvey PR, Nellist DR, Telfer MG (2002) Provisional atlas of British spiders (Arachnida, Araneae). Volumes $1 \& 2$. Huntingdon, Biological Records Centre

Hose GC, James JM, Gray MR (2002) Spider webs as environmental indicators. Environ Pollut 120:725-733

Jermann E, Hajimiragha H, Brockhaus A, Freier I, Ewers U, Roscovanu A (1989) Exposure of children to benzene and other motor vehicle emissions. Zentralbl Hyg Umweltmed 189:50-61

Laschober C, Limbeck A, Rendl J, Puxbaum H (2004) Particulate emissions from on-road vehicles in the Kaisermuhlen-Tunnel (Vienna, Austria). Atmos Environ 38:2187-2195

Liu Y, Chen L, Qing-hui H, Wei-ying L, Yin-jian T, Jian-fu Z (2009) Source apportionment of polycyclic aromatic hydrocarbons (PAHs) in surface sediments of the Huangpu River, Shanghai, China. Sci Total Environ 407:2931-2938
Nyffeller M, Moor H, Foelix RF (2001) Spiders feeding on earthworms. J Arachnol 29:119-124

Orecchio S, Gianguzza A, Culotta L (2008) Absorption of polycyclic aromatic hydrocarbons by Pinus bark: analytical method and use for environmental pollution monitoring in the Palermo area (Sicili, Italy). Environ Res 107:371-379

Orliński R (2002) Multipoint moss passive samples assessment of urban airborne polycyclic aromatic hydrocarbons: concentration profile and distribution along Warsaw main streets. Chemosphere 48:81-186

Ortega-Jiminez VM, Dudley R (2013) Spiderweb deformation induced by electrostatically charged insects. Sci Rep doi:10.1038/srep02108

Park JG, Moon MJ (2002) Fine structural analysis of the silk apparatus in the funnel web spider Agelena limbata (Araneae: Agelenidae). Korean J Entomol 32(4):223-232

Prajapati S, Triphati B (2008) Biomonitoring seasonal variation of urban air polycyclic aromatic hydrocarbons (PAHs) using Ficus benghalensis leaves. Environ Pollut 151:543-548

Ratola N, Amigo JM, Alves A (2010) Levels and sources of PAHs in selected sites from Portugal: biomonitoring with Pinus pinea and Pinus pinaster needles. Arch Environ Contam Toxicol 58:631-647

Ratola N, Alves A, Lacorte S, Barcel D (2012) Distribution and sources of PAHs using three pine species along the Ebro River. Environ Monit Assess 184:985-999

Roberts MJ (1995) Spiders of Britain and Northern Europe. Harper Collins Publishers, London

Rodriguez JH, Wannaz ED, Salazar MJ, Pignata ML, Fangmeier A, Franzaring J (2012) Accumulation of polycyclic aromatic hydrocarbons and heavy metals in the tree foliage of Ecalyptus rostrata, Pinus radiata and Populus hybridus in the vicinity of a large aluminum smelter in Argentina. Atmos Environ 55:35-42

Rogula W, Pastuszka JS, Talik E (2007) Concentration level and surface chemical composition of urban airborne particles near crossroads in Zabrze, Poland. Arch Ochr Srod 33(2):23-34

Rybak J (2007) Structure and function of the web Bathyphantes simillimus (Araneae: Linyphiidae) in an isolated population in the Stołowe Mountains, SW Poland. Bull Br Arachnol Soc 14(1):33-38

Rybak J, Sówka I, Zwozdziak A (2012) The preliminary assessment of use of spider webs for the indication of air contaminants. Environ Prot Eng 3:175-181

Shukla V, Upreti DK (2009) Polycyclic aromatic hydrocarbon (PAH) accumulation in lichen Phaeophyscia hispidula of DehraDun City, Garhwal Himalayas. Environ Monit Assess 149:1-7

Sapkota A, Buckley TJ (2003) The mobile source effect on curbside 1,3butadiene, benzene, and particle-bound polycyclic aromatic hydrocarbons assessed at a tollbooth. J Air Waste Manag 53(6):740-748

Suchecki B (2006) Wpływ transportu drogowego na zdrowie człowieka. Centrum Zrównoważonego Rozwoju, Zielone Mazowsze, Warszawa

Wingfors H, Sjodin A, Haglund P, Brorstrom-Lunden E (2001) Characterization and determination of profiles of polycyclic aromatic hydrocarbons in a traffic tunnel in Gothenburg, Sweden. Atmos Environ 35:6361-6369

Wojewódzki Inspektorat Ochrony Środowiska (2012) Raport o stanie środowiska w województwie dolnośląskim w 2011 roku. WIOŚ, Wrocław

Xiao-li S, Yu P, Hose GC, Jian C, Feng- Xiang L (2006) Spider webs as indicators of heavy metal pollution in air. Bul Environ Contam Toxicol 76(2):271-277

Zechmeister HG, Dullinger S, Hohenwallner D, Riss A, Hanus-Illnar A, Sharf S (2006) Pilot study on road traffic emissions (PAHs, heavy metals) measured by using mosses in a tunnel experiment in Vienna, Austria. Environ Sci Pollut R 13:398-405

Zhu Y, Hinds WC, Shen S, Kim S, Sioutas C (2002) Study of ultrafine particles near a major highway with heavy-duty diesel traffic. Atmos Environ 36:4323-4433

Zuo Q, Duan YH, Yang Y, Wang XJ, Tao S (2007) Source apportionment of polycyclic aromatic hydrocarbons in surface soil in Tianjin, China. Environ Pollut 147:303-310 